\title{
Characterization and Evaluation of some Cultivars of Sweet Pepper (Capsicum annuum)
}

\author{
Kolawole Edomwonyi LAW-OGBOMO, Joyce Egberanwen LAW-OGBOMO
}

Benson Idahosa University, Department of Agriculture, PMB 1100, Benin City, Nigeria; kolalawogbomo@yahoo.com

\begin{abstract}
Field trials were conducted to evaluate seven cultivars (both improved and local races) of sweet pepper in 2006 and 2007 at Evboneka a humid tropical environment in Nigeria to access agronomic characteristics and fruit yield. The study was conducted using a randomized complete block design (RCBD) with seven cultivars ('Tea 14,' 'California wonder Ps', 'California Wonder 300', 'N 22', N 23”' and 'Long yellow sweet') in three replications. Results from the trial showed that the cultivars produced varying vegetative, growth and yield characters. The 'Tea 14' produced the plants with superior vegetative characters and fruit yields (6.21 tha $\left.\mathrm{t}^{-1}\right)$ and the lowest being 'Benin local' $\left(2.02 \mathrm{t} \mathrm{ha}^{-1}\right)$. There were significant differences among all the genotypes tested. Higher fruit yields was obtained in 2006 with an average value of $3.86 \mathrm{t} \mathrm{ha}^{-1}$ and $3.84 \mathrm{t} \mathrm{ha}^{-1}$ obtained in 2007. The comparatively high yield potential (average yield of $3.85 \mathrm{tha}^{-1}$ ) recorded in the trial is an indication of a promising sweet pepper production in the humid tropical zone.
\end{abstract}

Keywords: cultivar evaluation, fruit yield, humid environment, mosaic disease virus, sweet pepper

\section{Introduction}

Pepper, Capsicum annuum, is the world's second most important Solanaceae vegetable after tomato (AVRDC, 1993). Sweet peppers are non-pungent with-walled fruits. The pericarp which can be non-pungent yet the placenta tissue can be hot (Remison, 2005). The crop is of tremendous economic and nutritional importance in Nigeria (Aliyu et al., 1976). It is rich in vitamins: A, B1, B3 and C. The provitamin A and ascorbic acid increases as sweet pepper mature. It is used in soups and stews; also eaten raw in salads. It can also been used for pickles and stuffing. As a medicinal plant, pepper is used in the production and treatment of cold and fever (Udoh et al., 2005).

Sweet peppers are attacked by a number of diseases caused by fungi, bacteria and virus. Among these diseases, the pepper mosaic disease was rated as the most paramount problem regardless of regions (Remison, 2005). The viral infection has not only resulted in yield loss but also in quality deterioration. In addition, the incidence of thrips, mites, aphids and whiteflies which are important virus vectors are also prevalent (Walter, 1986).

Despite the tremendous importance of sweet pepper, its cultivation in the humid tropics is low. However, sweet pepper plants are hardy and the potentials for its production is very high as the tropical soil is suitable, rainfall is not limiting and the crop can tolerate slightly acidic soils. There is no reason why the cultivation of this crop should not be encouraged and popularized particularly at this time. The government of Nigeria is re-focusing on agriculture as a non-crude oil foreign exchange earner. To acclimatize to the humid tropics, sweet pepper will have to gain tolerance to heat and other environmental stresses typical of the tropics as well as resistance to pepper mosaic viruses, early maturity, quality fruit characters, and high yield also have to be taken into consideration.

The need to intensify the production of sweet pepper even in the rain forest zone of the country is now apparent, therefore identification, selection and improvement of various genotypes suitable for the zone becomes very necessary.

This trial was undertaken to evaluate the performance of improved and local races of sweet pepper cultivars in humid tropical environment with respect to agronomic characteristics and yield potential to find promising cultivars that are suitable for the humid ultisol.

\section{Materials and methods}

The trials were conducted at Evboneka $\left(5^{\circ} 4^{\prime}\right.$ and $06^{\circ} 45^{\prime} \mathrm{E}$ between $5^{\circ} 45^{\prime}$ and $7^{\circ} 30^{\prime} \mathrm{N}$ ) during the dry season of 2006 and 2007, characterized by a tropical climate, lieing within the humid region. The study area lies within rainforest, which has degraded to secondary forest as a result of shifting cultivation. The site into which the trial was sited was previously cultivated with yam, melon and cassava and later allowed to fallow for two years before it was used for the trial. The dominant fallow plant species on the land was guinea grass (Panicum maximum). Meteorological data during the trial period (Tab. 1) were obtained from Information and Documentation, Nigerian Institute for Oil Palm Research (NIFOR), Benin City.

Composite soil sample was collected at 0-30 cm depth from the site using an auger. The samples were sieved to 
50

Tab. 1. Weather data at Evboneka (humid tropical environment)

\begin{tabular}{ccccccccccccc}
\hline Month & \multicolumn{9}{c}{2006} & \multicolumn{7}{c}{2007} \\
\hline & $\begin{array}{c}\text { Rainfall } \\
(\mathrm{cm})\end{array}$ & Sunshine & \multicolumn{2}{c}{$\begin{array}{c}\text { Relative } \\
\text { humidity }(\%)\end{array}$} & Air temperature & $\begin{array}{c}\text { Rainfall } \\
(\mathrm{cm})\end{array}$ & $\begin{array}{c}\text { Sunshine } \\
\text { humidity }(\%)\end{array}$ & $\begin{array}{c}\text { Relative } \\
\text { huir temperature }\end{array}$ \\
\hline January & 22.50 & 4.40 & 85.70 & 61.10 & 33.70 & 22.60 & 0.00 & 7.50 & 59.70 & 33.50 & 34.70 & 17.80 \\
\hline February & 10.50 & 4.70 & 81.80 & 57.80 & 35.90 & 22.50 & 104.20 & 7.40 & 80.80 & 50.60 & 34.90 & 21.50 \\
\hline March & 61.10 & 2.90 & 81.90 & 60.00 & 33.70 & 22.40 & 56.20 & 5.80 & 81.40 & 50.80 & 33.80 & 22.60 \\
\hline April & 158.00 & 4.80 & 82.10 & 61.60 & 34.30 & 23.20 & 197.70 & 5.20 & 80.80 & 67.40 & 33.90 & 21.30 \\
\hline May & 246.80 & 3.70 & 82.70 & 72.60 & 31.20 & 21.50 & 246.20 & 6.10 & 82.30 & 68.60 & 32.50 & 21.00 \\
\hline June & 172.50 & 4.60 & 84.00 & 70.60 & 30.60 & 20.80 & 380.90 & 5.60 & 76.50 & 66.50 & 27.60 & 18.30 \\
\hline July & 289.00 & 2.30 & 86.20 & 78.00 & 29.50 & 21.10 & 284.70 & 4.40 & 87.00 & 79.50 & 29.40 & 21.50 \\
\hline August & 335.90 & 1.40 & 84.40 & 83.00 & 28.30 & 20.80 & 171.40 & 2.70 & 92.00 & 86.00 & 28.00 & 23.00 \\
\hline September & 347.40 & 2.00 & 85.70 & 81.00 & 30.90 & 19.70 & 256.00 & 3.90 & 78.70 & 72.20 & 28.70 & 20.20 \\
\hline October & 304.50 & 3.50 & 84.70 & 70.40 & 31.00 & 20.80 & 285.00 & 5.90 & 76.00 & 64.00 & 29.00 & 20.00 \\
\hline November & 24.70 & 5.70 & 78.80 & 56.50 & 33.30 & 19.10 & 37.10 & 7.50 & 59.60 & 47.80 & 24.30 & 16.50 \\
\hline December & 0.00 & 5.80 & 76.40 & 49.40 & 34.00 & 18.16 & 17.00 & 7.40 & 74.80 & 54.50 & 32.60 & 19.70 \\
\hline Total & 1972.90 & 45.80 & 988.40 & 804.00 & 386.40 & 253.10 & 2036.50 & 70.40 & 929.60 & 741.40 & 369.40 & 243.40 \\
\hline Mean & 164.40 & 3.80 & 83.20 & 67.00 & 32.20 & 21.10 & 169.70 & 5.90 & 74.50 & 61.80 & 30.80 & 20.30 \\
\hline
\end{tabular}

Source: Documentation and Information Department, Nigerian Institute for Oil Palm Research, NIFOR.

remove roots, leaves and stones. The sample was air-dried for two weeks and routinely analyzed for the soil physical and chemical properties prior to planting using standard laboratory procedures described by Mylavarapus and Kennelley (2002). Data obtained were presented in Tab. 2.

The experimental layout was a randomized complete block design involving seven cultivars viz: 'Tea 14', 'California wonder Ps' , 'California Wonder 300' , 'N 22' , 'N

Tab. 2. Physical and chemical properties of the experimental sites

\begin{tabular}{|c|c|c|}
\hline \multirow[t]{2}{*}{ Properties } & \multicolumn{2}{|c|}{ Year } \\
\hline & 2006 & 2007 \\
\hline $\mathrm{pH}\left(\mathrm{H}_{2} \mathrm{O}\right)$ & 5.40 & 5.50 \\
\hline Organic carbon (\%) & 0.30 & 0.35 \\
\hline Total nitrogen $(\%)$ & 0.07 & 0.08 \\
\hline Available phophorus $\mathrm{mg} \mathrm{kg}^{-1}$ & 9.25 & 9.50 \\
\hline \multicolumn{3}{|c|}{ Exchangeable cations $\left(\mathrm{c} \mathrm{mol} \mathrm{kg}{ }^{-1}\right)$} \\
\hline $\mathrm{Ca}^{2+}$ & 0.20 & 0.22 \\
\hline $\mathrm{Mg}^{2+}$ & 0.44 & 0.47 \\
\hline $\mathrm{K}^{+}$ & 0.11 & 0.13 \\
\hline $\mathrm{Na}^{+}$ & 0.07 & 0.09 \\
\hline Exchangeable acidity $\left(\mathrm{c} \mathrm{mol} \mathrm{kg}^{-1}\right)$ & 0.04 & 0.30 \\
\hline Base saturation (\%) & 67.21 & 0.75 \\
\hline Sand $\mathrm{g} \mathrm{kg}^{-1}$ & 600.00 & 570.00 \\
\hline Silt $\mathrm{g} \mathrm{kg}^{-1}$ & 275.00 & 330.00 \\
\hline Clay g kg-1 & 125.00 & 100.00 \\
\hline
\end{tabular}

23 ' and 'Long yellow sweet' with three replications. The gross and net plot sizes were $24 \mathrm{~m}^{2}$ and $17.6 \mathrm{~m}^{2}$, respectively.

Each year, the experimental site was ploughed and harrowed once. Ridges were constructed $100 \mathrm{~cm}$ apart with plants set at $60 \mathrm{~cm}$ within row. The seedlings of the seven cultivars were raised in the seed box by broadcasting the seeds in shallow drills and keep under shade. Prior to transplanting, 3-4 granules of carbofuran (Furadan 5G) were placed in each hole to guard against insect and termite attack. Five weeks old seedlings were transplanted on November $20^{\text {th }}$ in the evening, followed by mulching. Crop filling was done a week later to replace missing stands. Manual weeding was done at four and eight weeks after transplanting (WAT). NPK 15:15:15 fertilizer at the rate of $200 \mathrm{~kg} \mathrm{ha}^{-1}$ was applied at two WAT each year by band placement. Plants were irrigated regularly using watering can in the morning so that the plant leaves would be dry before nightfall. The plants were pinched at three WAT using a pair of shear for more branches to form so that they would produce more fruits.

Plant height and number of branches were determined in-site from eight randomly sampled plants from the net plots. Leaf discs were punched out with a cork borer and the relationship between area and dry weight of the disc was used to estimate leaf area (Remison, 1997). From the leaf area, leaf area index (LAI) was computed as it follows:

LAI $=$ Leaf area/Land area (Remison, 1997).

Records were taken from 4 to 12 WAT on four weekly intervals. 42 plants, two from a plot, were removed at 
random at four, eight and $12 \mathrm{WAP}$, dried at $70^{\circ} \mathrm{C}$ for 72 hours to constant weight (ISTA, 1993) to obtained total dry matter. Crop growth rate (C) was computed from total dry matter:

$\mathrm{C}=\mathrm{W}_{1}-\mathrm{W}_{2} / \mathrm{T}_{1}-\mathrm{T}_{2} \mathrm{gm}^{-2} \mathrm{wk}^{-1}$ (Remison, 1997).

i.e change in total dry matter over a given period

Where $\quad W_{1}=$ Total dry matter at one sampling $\mathrm{W}_{2}=$ Total dry matter at next sampling

sampling.

$\mathrm{T}_{1}-\mathrm{T}_{2}=$ The number of weeks between

Fresh fruit yield per plant were collected on plant basis from tagged plants. Days to $50 \%$ flowering were recorded on plot basis. Harvesting was conducted when fruit reached full size, firm, but had not yet changed colour. Fresh fruit yield per hectare was obtained through conversion of the net plot yield (Law-Ogbomo, 2007).

Analysis of variance was carried out on vegetative, growth and yield data recorded for each year of study, followed by combined analysis over two years. The Least Significant Difference (LSD) test was used for detecting significance differences between means at 5\% level of probability. Linear correlations linking variables were also computed in GENSTAT programme, version 8.1 (Genstat, 2005).

\section{Results and discussion}

\section{Soil native fertility}

The results of the physical and chemical analysis of the experimental sites presented in Tab. 2 shows that the soil is acidic sandy loam (ultisol) with low nutrient status since they contain less than the critical levels of nutrients in the soil (Ibedu et al., 1988).

\section{Vegetative traits}

Evaluation of some cultivars on plant height and number of branches at 3, 6 and 9 WAT are showed in Tab. 3 . Generally, there were significant differences among the cultivars in response to plant height and number of branches at 3, 6 and 9 WAT. The height of plant is an important growth character directly linked with the productive potential of plant. An optimum plant height is claimed to be positively correlated with productivity of plant (Saeed $e t$ al., 2001). Plant height generally increased progressively throughout the sampling periods, varying from 14.45 for 'Benin local' to $18.30 \mathrm{~cm}$ for 'N 22' at three WAT. The number of branches follow the same trend as the plant height with 'Benin local' having the least (3.41) while 'Tea $14^{\prime}$ had the highest number of branches (4.65) at three WAT.

At 6 WAT, 'N 22' still maintained the highest between plants $(26.41 \mathrm{~cm})$, 'Tea 14' had the highest number of branches (13.36). The 'Long yellow sweet' presented the shortest $(17.46 \mathrm{~cm})$ while 'Benin local' had the least number of branches (8.89).
At 9 WAT, the plant height showed a range of $24.43 \mathrm{~cm}$ and $36.60 \mathrm{~cm}$ and there were significant differences among the cultivars. The 'Benin local' showed the least $(24.23 \mathrm{~cm})$ while the 'N 22' had the highest $(36.60 \mathrm{~cm})$. The 'Benin local' had the least in number of branches (11.49) while 'Tea 14' had the highest number of branches (22.22).

\section{Growth Analysis}

The influence of cultivars on growth is presented in Tab. 4. The number of leaves showed a ranged from 11.83 to 18.17 per plant and there were significant differences among the cultivars at 4 WAT. The 'Tea 14' had the highest (18.17) while 'Benin local' had the least (11.83). The LAI and total dry matter followed the same trend as the number of leaves with 'Benin local' having the least (0.04) while 'Tea 14' had the greatest LAI (0.05) and 'Tea 14' produced the greatest $\left(0.70 \mathrm{~kg} \mathrm{wk}^{-1}\right)$ at four WAT.

At 8 WAT, 'Tea 14' maintained the highest number of leaves (44.17), LAI (0.69) and biological yield $(1.17 \mathrm{~kg}$ $\left.\mathrm{wk}^{-1}\right)$. The 'Benin local' had the least in number of leaves (30.17), LAI (0.18) and total dry matter (0.42).

At 12 WAT, the trend still did not change and there was a marked variation among the cultivars. The number of leaves variation among cultivars was probably due to pepper mosaic virus infection. The 'Long yellow sweet' cultivar was highly prone to this disease while 'California wonder Ps' and 'California Wonder 300' were mildly infected and 'Tea 14', 'N 22', 'N 23' and 'Benin local' were not affected by this infection. This was evidenced through the scale of infection on the leaves and plant height. However, the 'Benin local' was unaffected by this disease but has low inherent ability to produce leaves. The severity of this infection on the susceptible and mild resistant varieties led to premature senescence resulting in lower number of leaves produced per plant.

The number of leaves mirrored the trend in LAI and dry matter accumulation (total dry matter) as number of leaves was significantly correlated with LAI and dry matter accumulation at 12 WAT with correlation coefficient of 0.66 and 0.67 , respectively.

The influence of cultivars on crop growth rate (CGR) is presented in Tab. 5. At 4-8 WAT, the CGR showed a range of 0.04 ('Benin local') and 0.10 ('Tea 14'), there were significant differences among the cultivars. However, at 8-12 WAT, it was observed that the CGR was the lowest $(0.06$ $\left.\mathrm{g} \mathrm{m}^{-2} \mathrm{wk}^{-1}\right)$ at 'Long yellow sweet' and the highest $(0.17 \mathrm{~g}$ $\left.\mathrm{m}^{-2} \mathrm{wk}^{-1}\right)$ at 'California wonder Ps'. Significant differences were observed among cultivars.

\section{Yield}

The effect of cultivars on yield of sweet pepper is presented in Tab. 6. The earliest to $50 \%$ flowering was 'Benin local' with 61.83 days while 'California Wonder 300' had the longest days (81.50). Significantly higher values were observed for number of days to $50 \%$ flowering in 2007 . 
Tab. 4. Evaluation of some cultivars of $C$. annuum for growth

\begin{tabular}{|c|c|c|c|c|c|c|c|c|c|}
\hline \multirow[t]{3}{*}{ Cultivars } & \multicolumn{3}{|c|}{ Number of leaves } & \multicolumn{3}{|c|}{ Leaf area index } & \multicolumn{3}{|c|}{ Total dry matter $\left(\mathrm{t} \mathrm{ha}^{-1}\right)$} \\
\hline & \multicolumn{3}{|c|}{ Weeks after transplanting } & \multicolumn{3}{|c|}{ Weeks after transplanting } & \multicolumn{3}{|c|}{ Weeks after transplanting } \\
\hline & 4 & 8 & 12 & 4 & 8 & 12 & 4 & 8 & 12 \\
\hline \multicolumn{10}{|c|}{2006} \\
\hline Tea 14 & 19.00 & 44.00 & 63.00 & 0.15 & 0.07 & 1.08 & 0.67 & 1.05 & 1.55 \\
\hline 'California wonder Ps' & 16.00 & 38.00 & 54.67 & 0.10 & 0.40 & 0.75 & 0.56 & 0.78 & 1.44 \\
\hline 'California wonder $300 ’$ & 16.67 & 37.67 & 54.00 & 0.10 & 0.45 & 0.71 & 0.56 & 0.94 & 1.28 \\
\hline 'Benin local' & 12.00 & 29.69 & 39.33 & 0.04 & 0.19 & 0.36 & 0.39 & 0.61 & 1.11 \\
\hline 'N 22' & 16.67 & 39.67 & 59.33 & 0.13 & 0.56 & 0.92 & 0.67 & 0.94 & 1.28 \\
\hline 'N 23' & 16.00 & 40.00 & 60.33 & 0.11 & 0.57 & 0.11 & 0.67 & 0.83 & 1.28 \\
\hline 'Long yellow sweet' & 13.33 & 30.33 & 43.67 & 0.07 & 0.30 & 0.48 & 0.41 & 0.83 & 1.11 \\
\hline Mean & 15.67 & 37.05 & 53.48 & 0.10 & 0.45 & 0.74 & 0.56 & 0.86 & 1.29 \\
\hline Standard error & 0.81 & 0.992 & 1.305 & 0.006 & 0.017 & 0.038 & 0.116 & 0.125 & 0.115 \\
\hline $\operatorname{LSD}(0.05)$ & 1.772 & 2.992 & 2.84 & 0.013 & 0.038 & 0.083 & 0.252 & 0.273 & 0.249 \\
\hline \multicolumn{10}{|c|}{2007} \\
\hline Tea 14 & 17.33 & 44.33 & 62.00 & 0.14 & 0.69 & 1.06 & 0.72 & 1.28 & 1.61 \\
\hline 'California wonder Ps' & 15.67 & 38.67 & 53.00 & 0.09 & 0.46 & 0.72 & 0.50 & 0.72 & 1.39 \\
\hline 'California wonder $300 ’$ & 15.00 & 36.67 & 53.00 & 0.09 & 0.41 & 0.70 & 0.56 & 0.89 & 1.17 \\
\hline 'Benin local' & 11.61 & 30.67 & 40.00 & 0.04 & 0.17 & 0.38 & 0.44 & 0.56 & 1.22 \\
\hline 'N 22' & 16.67 & 38.33 & 59.33 & 0.12 & 0.46 & 0.91 & 0.61 & 1.00 & 1.22 \\
\hline 'N 23' & 15.00 & 39.33 & 59.67 & 0.11 & 0.55 & 0.91 & 0.61 & 0.83 & 1.06 \\
\hline 'Long yellow sweet' & 13.33 & 30.67 & 41.00 & 0.07 & 0.30 & 0.46 & 0.44 & 0.89 & 1.27 \\
\hline Mean & 14.95 & 36.85 & 52.57 & 0.09 & 0.43 & 0.73 & 0.56 & 0.88 & 1.28 \\
\hline Standard error & 1.317 & 2.344 & 1.478 & 0.008 & 0.051 & 0.025 & 0.066 & 0.071 & 0.062 \\
\hline $\operatorname{LSD}(0.05)$ & 2.870 & 5.106 & 3.221 & 0.018 & 0.108 & 0.052 & 0.144 & 0.154 & 0.135 \\
\hline \multicolumn{10}{|c|}{ Combined } \\
\hline Tea 14 & 18.17 & 44.17 & 62.50 & 0.15 & 0.69 & 1.07 & 0.70 & 1.17 & 1.58 \\
\hline 'California wonder Ps' & 15.83 & 38.33 & 53.83 & 0.10 & 0.46 & 0.74 & 0.53 & 0.75 & 1.42 \\
\hline 'California wonder 300 ’ & 15.83 & 37.17 & 53.50 & 0.10 & 0.43 & 0.70 & 0.56 & 0.92 & 1.25 \\
\hline 'Benin local' & 11.83 & 30.17 & 39.67 & 0.04 & 0.18 & 0.37 & 0.42 & 0.59 & 1.14 \\
\hline 'N 22' & 16.67 & 39.00 & 59.33 & 0.12 & 0.51 & 0.92 & 0.64 & 0.97 & 1.25 \\
\hline 'N 23' & 15.50 & 39.67 & 60.00 & 0.11 & 0.56 & 0.91 & 0.64 & 0.83 & 1.25 \\
\hline 'Long yellow sweet' & 13.33 & 30.50 & 42.33 & 0.07 & 0.30 & 0.47 & 0.43 & 0.86 & 1.09 \\
\hline Mean & 15.31 & 37.00 & 53.02 & 0.10 & 0.45 & 0.74 & 0.56 & 0.87 & 1.282 \\
\hline Standard error & 0.752 & 1.129 & 0.977 & 0.006 & 0.027 & 0.020 & 0.067 & 0.070 & 0.061 \\
\hline $\operatorname{LSD}(0.05)$ & 1.530 & 2.297 & 1.988 & 0.011 & 0.056 & 0.04 & 0.137 & 0.142 & 0.123 \\
\hline
\end{tabular}

Days to $50 \%$ flowering was positively corrected to plant height $(\mathrm{r}=0.68)$.

The fruit yield was not the same among the cultivars. The highest fruit yield per plant was obtained from 'Tea 14 ' with $373.17 \mathrm{~g}$ while 'Benin local' had the least fruit yield per plant $(121.33 \mathrm{~g})$. The fruit yield per hectare range from 2.02 to $6.21 \mathrm{t} \mathrm{ha}^{-1}$. The differences among the cultivars were significant. The trend of distribution among cultivars was significant. The trend of distribution among cultivars was the same as that of the fruit yield per plant. The 'Tea 14' produced the greatest fruit yield per hectare $\left(6.21 \mathrm{t} \mathrm{ha}^{-1}\right)$ while the least was produced by 'Benin local'. This could be probably due to better responses in terms of number of leaves and LAI. These traits resulted in the greatest light interception accrued to this cultivar ('Tea 14') leading to the production of greater amount of photosynthetates. This accounts for its highest average fruit yield. Fruit yield was found to be highly negatively correlated to days to $50 \%$ flowering $(r=0.73)$. Higher fruit yields were obtained in 2006 with a mean value of $3.86 \mathrm{t}$ ha $^{-1}$ compared with $3.84 \mathrm{t} \mathrm{ha}^{-1}$ recorded in 2007. Although higher total annual rainfall, sunshine, relative humidity and air temperature were experienced in 2007 than 2006. Rainfall was more uniformly distributed in 2006 than 2007 (Tab. 1). 
Tab. 5. Evaluation of some cultivars of C. annuum for crop growth rate

\begin{tabular}{|c|c|c|}
\hline Cultivars & \multicolumn{2}{|c|}{ Weeks after transplanting } \\
\hline & $\mathrm{C} 1$ & $\mathrm{C} 2$ \\
\hline & $(4-8)$ & $(8-12)$ \\
\hline \multicolumn{3}{|c|}{2006} \\
\hline 'Tea 14' & 0.10 & 0.13 \\
\hline 'California wonder Ps' & 0.05 & 0.17 \\
\hline 'California wonder 300 ' & 0.08 & 0.08 \\
\hline 'Benin local' & 0.06 & 0.13 \\
\hline 'N 22' & 0.07 & 0.08 \\
\hline 'N 23' & 0.04 & 0.11 \\
\hline 'Long yellow sweet' & 0.07 & 0.07 \\
\hline Mean & 0.07 & 0.11 \\
\hline Standard error & 0.03 & 0.04 \\
\hline $\operatorname{LSD}(0.05)$ & $\mathrm{ns}$ & ns \\
\hline \multicolumn{3}{|c|}{2007} \\
\hline 'Tea 14' & 0.09 & 0.09 \\
\hline 'California wonder Ps' & 0.05 & 0.17 \\
\hline 'California wonder 300 ' & 0.08 & 0.10 \\
\hline Benin local' & 0.03 & 0.14 \\
\hline 'N 22' & 0.10 & 0.05 \\
\hline 'N 23' & 0.05 & 0.10 \\
\hline 'Long yellow sweet' & 0.11 & 0.04 \\
\hline Mean & 0.07 & 0.099 \\
\hline Standard error & 0.031 & 0.025 \\
\hline $\operatorname{LSD}(0.05)$ & 0.068 & 0.056 \\
\hline \multicolumn{3}{|c|}{ Combined } \\
\hline 'Tea 14’ & 0.10 & 0.11 \\
\hline 'California wonder Ps' & 0.05 & 0.17 \\
\hline 'California wonder 300 ' & 0.08 & 0.09 \\
\hline 'Benin local' & 0.04 & 0.14 \\
\hline 'N 22' & 0.08 & 0.07 \\
\hline 'N 23' & 0.05 & 0.11 \\
\hline 'Long yellow sweet' & 0.09 & 0.06 \\
\hline Mean & 0.07 & 0.11 \\
\hline Standard error & 0.023 & 0.023 \\
\hline $\operatorname{LSD}(0.05)$ & 0.047 & 0.047 \\
\hline
\end{tabular}

ns-not significant

From the trial, it was revealed that all the evaluated cultivars performed well and exceeds African average (1.00 $\left.\mathrm{t} \mathrm{ha}^{-1}\right)$ FAO, 2006). This was probably due to improved cultural practice, employed during the course of the trial. The optimal fruit yield was produced by the 'Tea 14', being the best yielding cultivar, also showing resistance to pepper mosaic virus infection and therefore recommended for farmers in this zone to maintain its high yield potential in the event of serious pepper mosaic virus attack. However, since the 'Benin local' was hardy, its fruit yield could be
Tab. 6. Evaluation of some cultivars of $C$. annuum for economic yield

\begin{tabular}{|c|c|c|c|}
\hline \multirow[t]{2}{*}{ Cultivars } & \multirow{2}{*}{$\begin{array}{c}\text { Days to } 50 \% \\
\text { flowering }\end{array}$} & \multicolumn{2}{|c|}{ Fruit yield } \\
\hline & & Yield plant ${ }^{-1}$ & Yield hectare $^{-1}$ \\
\hline \multicolumn{4}{|c|}{2006} \\
\hline 'Tea 14’ & 73.67 & 347.33 & 6.24 \\
\hline 'California wonder Ps' & 79.00 & 179.67 & 3.00 \\
\hline $\begin{array}{l}\text { 'California } \\
\text { wonder } 300 \text { ' }\end{array}$ & 81.00 & 185.33 & 3.09 \\
\hline 'Benin local' & 61.00 & 119.67 & 2.00 \\
\hline 'N22' & 72.33 & 268.67 & 4.48 \\
\hline 'N 23' & 75.33 & 255.00 & 4.25 \\
\hline 'Long yellow sweet' & 77.33 & 239.33 & 3.99 \\
\hline Mean & 74.24 & 231.71 & 3.86 \\
\hline Standard error & 1.266 & 1.972 & 0.032 \\
\hline $\operatorname{LSD}(0.05)$ & 2.759 & 4.297 & 0.071 \\
\hline \multicolumn{4}{|c|}{2007} \\
\hline 'Tea 14' & 74.33 & 372.00 & 6.20 \\
\hline 'California wonder Ps' & 79.00 & 180.00 & 3.00 \\
\hline $\begin{array}{l}\text { 'California } \\
\text { wonder } 300 \text { ' }\end{array}$ & 82.00 & 185.33 & 3.09 \\
\hline 'Benin local' & 62.67 & 123.00 & 2.05 \\
\hline 'N 22' & 72.33 & 263.67 & 4.40 \\
\hline 'N 23' & 74.00 & 253.33 & 4.22 \\
\hline 'Long yellow sweet' & 77.00 & 253.33 & 3.92 \\
\hline Mean & 74.48 & 230.38 & 3.84 \\
\hline Standard error & 1.307 & 1.127 & 0.018 \\
\hline $\operatorname{LSD}(0.05)$ & 2.848 & 2.455 & 0.038 \\
\hline \multicolumn{4}{|c|}{ Combined } \\
\hline 'Tea 14' & 74.00 & 373.17 & 6.21 \\
\hline 'California wonder Ps' & 79.00 & 179.83 & 3.00 \\
\hline $\begin{array}{l}\text { 'California } \\
\text { wonder } 300 \text { ' }\end{array}$ & 81.50 & 185.33 & 3.09 \\
\hline 'Benin local' & 61.83 & 121.33 & 2.02 \\
\hline 'N 22' & 72.33 & 266.17 & 4.44 \\
\hline 'N 23' & 74.67 & 254.17 & 4.24 \\
\hline 'Long yellow sweet' & 77.17 & 237.33 & 3.96 \\
\hline Mean & 74.36 & 231.05 & 3.85 \\
\hline Standard error & 0.881 & 1.375 & 0.022 \\
\hline LSD (0.05) & 1.792 & 2.798 & 0.045 \\
\hline
\end{tabular}

improved by crossing with 'Long yellow sweet' in order to improve.

\section{References}

Aliyu, U. L., Y. Yusuf and M. K. Ahmed (1996). Response of pepper to fertilizers: growth, yield and yield components as affected by nitrogen and phosphorus levels. Proceeding of $14^{\text {th }}$ HORTON Conference, Ago-Iwoye, Ogun State, 1-4 April, 1996. Published by The Horticultural Society of Nigeria, Ibadan. 
54

AVRDC (1993). Breeding of solanaceous and cole crops. AVRDC, Shanhua, Tainan, Taiwan, p. 85-100.

GENSTAT (2005). Gentstat Release 8.1. Statistical Software. VSN International Ltd, Rothamsted, UK.

FAO (2006). Food and Agriculture Organisation (2006). FAOSTAT. FAO Statistic Division, Rome.

Ibedu, M. A., R. P. A. Unambra and A. Udealor (1988). Soil management strategies in relation to farming system development in Southwestern Agricultural zone of Nigeria. Paper presented at the National Farming System Research Workshop, Jos, Plateau State, Nigeria.

ISTA (1993). International Rules for Seed Testing Association. The determination of moisture content and number of seed in ccession. Seed Science and Technology, Supplementary rules, 21, 24-33.

Law-Ogbomo, K. E. (2007). Agronomic evaluation of white yam (Dioscorea rotundata Poir) in different ecological zones of Edo State, Nigeria. Ph.D Thesis, University of Benin, Benin City, Nigeria.
Mylavarapus, R. S. and D. E. Kennelley (2002). UF//IFAS extension soil testing laboratory (ESTL): Analytical procedures and training manual. Institute of Food and Agricultural Science, University of Florida, Gainsville, USA, p.28.

Remison, S. U. (1997). Basic principles of crop physiology. Sadoh Press (Nig.), Benin City.

Remison, S. U. (2005). Arable and vegetable crops. Gift-Press Associates Publishers, Benin City.

Saeed, I. N., K. Abbasi and M. Kazim (2001). Response of maize (Zea mays) to nitrogen and phosphorus fertilization under agro-climatic condition of Rawalokot Azad Jammu and Kashmir. Pak. J. Biol. Sci. 4:53-55.

Udoh, D. J., B. A. Ndon, P. E. Asuquo and N. U. Ndaeyo (2005). Crop production techniques for the tropics. Concept Publications (Press Division), Lagos. p. 464 .

Walter, H. (1986). Pepper breeding. In: Breeding vegetable crops. Westport, Connecticut: AVI Publishing Co. 